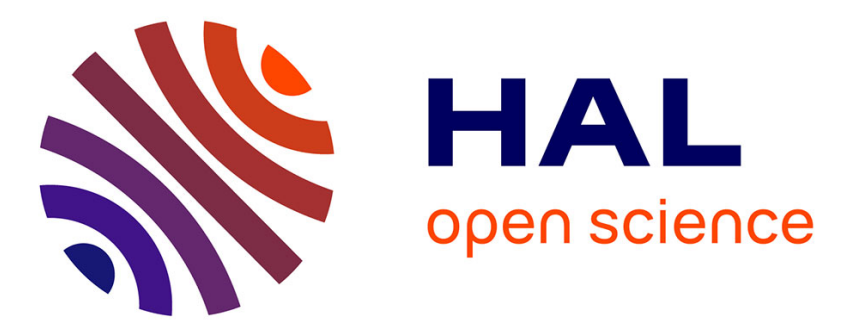

\title{
Improving the articles about modern art in Wikipedia: a partnership between Wikimédia France and the Pompidou Centre
}

Sylvain Machefert

\section{- To cite this version:}

Sylvain Machefert. Improving the articles about modern art in Wikipedia: a partnership between Wikimédia France and the Pompidou Centre. Art Libraries Journal, 2015, 40 (03), pp.34-40. hal01971651

\section{HAL Id: hal-01971651 \\ https://hal.science/hal-01971651}

Submitted on 7 Jan 2019

HAL is a multi-disciplinary open access archive for the deposit and dissemination of scientific research documents, whether they are published or not. The documents may come from teaching and research institutions in France or abroad, or from public or private research centers.
L'archive ouverte pluridisciplinaire HAL, est destinée au dépôt et à la diffusion de documents scientifiques de niveau recherche, publiés ou non, émanant des établissements d'enseignement et de recherche français ou étrangers, des laboratoires publics ou privés. 


\section{Improving the articles about modern art in Wikipédia: a partnership between Wikimédia France and the Pompidou Centre}

\section{Sylvain Machefert}

Museums have seen the ubiquitousness of Wikipedia use and started to open up their data to reuse on the Internet. This is an effort to both improve the information available to casual users and researchers and to make images and information from their holdings more accessible. In a paper originally delivered at the IFLA Art Libraries Section pre-conference in August 2014, Sylvain Machefert, a university systems librarian, describes some of his activities as a member of Wikimédia France. A project between the Centre Pompidou and Wikipédia designed to involve the art-loving public, as well as those with more expert art experience, serves as a case study. He assesses the project's strengths and weaknesses on the basis of its outcomes. He touches on some other projects that have also contributed to the improvement of art information available through one of France's and the world's most popular general web services.

Wikimédia France - Association pour le libre partage de la connaissance is a non-profit organization. Its aim is to support the free dissemination of knowledge, especially those projects that are hosted by the Wikimedia Foundation. Amongst these are the encyclopedia Wikipedia and the media repository Wikimedia Commons.

The Pompidou Centre is a multi-disciplinary cultural establishment in Paris which is dedicated to modern and contemporary creation. The Centre houses the premier European art collection in these fields, and its orientation towards modern and contemporary art has important implications for the partnership described in this article.

\section{The partnership}

\section{Context}

Given the growing importance on the web of Wikipedia, cultural institutions in France have begun to study what opportunities it makes possible to them. Although it is not essential, most 
establishments that have chosen to work with Wikipedia and the projects associated with it have made use of Wikimédia France which, while it has no editorial power over the projects, acts as a facilitator between the cultural bodies involved and the wikimedians. ${ }^{1}$

Cultural partnerships between the Wikimedia movement and cultural institutions, such as galleries, libraries, archives and museums, are known collectively as GLAMs. In France the first wideranging GLAM partnership was carried out in $2010^{2}$ with the Bibliothèque nationale de France $(\mathrm{BnF})$, which chose to upload some 1400 works in the public domain into Wikimedia Commons, the free media repository. The objective was to control and improve the BnF's OCR, ${ }^{3}$ which was being created in an automatic manner.

\section{Objectives of the partnership}

The links between the Centre Pompidou and Wikimédia France began in June $2011^{4}$ with the establishment of two working parties, whose members visited the Centre's collections and edited a number of articles about them. As a result of the success of this first experiment, combined with the launch of Centre Pompidou Virtuel ${ }^{5}$, the two working parties continued their work during the course of the 2013-2014 academic year.

The partnership signed on 18 September 2013 between the Centre Pompidou and Wikimédia France included considerably enhanced ambitions compared with 2011. It anticipated that 'about one hundred works will be presented by the 50 first participants with the aim of creating the same number of articles on Wikipédia, over a period of six months'. ${ }^{6}$ It also announced a further objective $^{7}$, namely that two 'good articles' and two 'articles of quality' would be achieved. ${ }^{8}$ Attributing such labels, a decision that has to be made by the community, is particularly demanding because these descriptors are given to less than one article in 450 .

\section{The Wikimedia 'ecosystem'}

Many initiatives have developed around the Wikimedia 'engine', the most important being the Wikimedia projects. There are now nearly a dozen such projects, built on the same system as Wikipedia itself. Using this model, there are now projects such as a dictionary (wiktionary), a library of works in the public domain (wikisource), a repository which stores the data used in wiki projects centrally (wikidata), and so on.

All these projects are managed by the Wikimedia Foundation, a non-profit organisation based in California and created in 2003, two years after the launch of Wikipedia. The Foundation is given support by local associations, whose aim is to ensure the promotion of projects in their particular 
geographical region. At the time of writing there were nearly 40 such associations, called 'chapters'.

\section{Wikipedia}

It is probably unnecessary to discuss here how Wikipedia functions, as it is relatively well-known nowadays, but it is perhaps useful to remind readers what a 'wiki' is: namely that it is a means by which any visitor to the site can easily modify the page which they are in the process of consulting.

Wikipedia is governed by five founding principles: ${ }^{9}$

1. Wikipedia is an encyclopaedia

2. Wikipedia is written from a neutral point of view

3. Wikipedia is published under an open source licence; anyone can use, edit and distribute its free content

4. Wikipedia follows the rules of good manners

5. (Wikipedia has no other fixed rules)

Beyond these principles, each linguistic community (and there are more than 280 of them) defines its own independent internal principles of organization (the types of article which are acceptable, rules for the election of the administrators $\left.{ }^{10} \ldots\right)$.

\section{Q Image sur le site du Musée national d'art moderne}

Figure 1 - Images from external site: Image from the site of Musée nationale de l'art moderne Wikipedia message that appears for images without copyright permission

The third of these founding principles, open source licensing, has a particular impact on the Pompidou Centre wiki project, because it implies that all the content in Wikipedia is available for re-use. Although one cannot take information from a published monograph and copy it into Wikipedia, it is possible to summarise or reformulate that information, since legal protection under copyright does not apply to ideas. However a problem arises with images. If a museum has negotiated permission with the rights-holders' to put an illustration onto its website, that permission does not extend to Wikipedia since this would mean that the image was available to everyone and for any use. This would certainly not be compatible with what the Pompidou Centre, for example, is allowed to do with the images. 


\section{The working groups}

After the agreement with the Pompidou Centre was signed, two kinds of group were launched:

1. a series of public workshops, held between September 2013 and March 2014, split into approximately 20 two-hour sessions; these focused on the collections

2. work events organised at the Bibliothèque Kandinsky around the catalogue of the programme 'History of exhibitions'. There were fewer of these workshops (four sessions), however they were longer (four hours each) and intended for more targeted participants.

\section{Public workshops}

The first series of workshops concentrated on an introduction about how to contribute to Wikipedia (creating an account, work on how an article is structured...) and on visits to the collections; these were followed by a second series devoted to the editing of the articles.
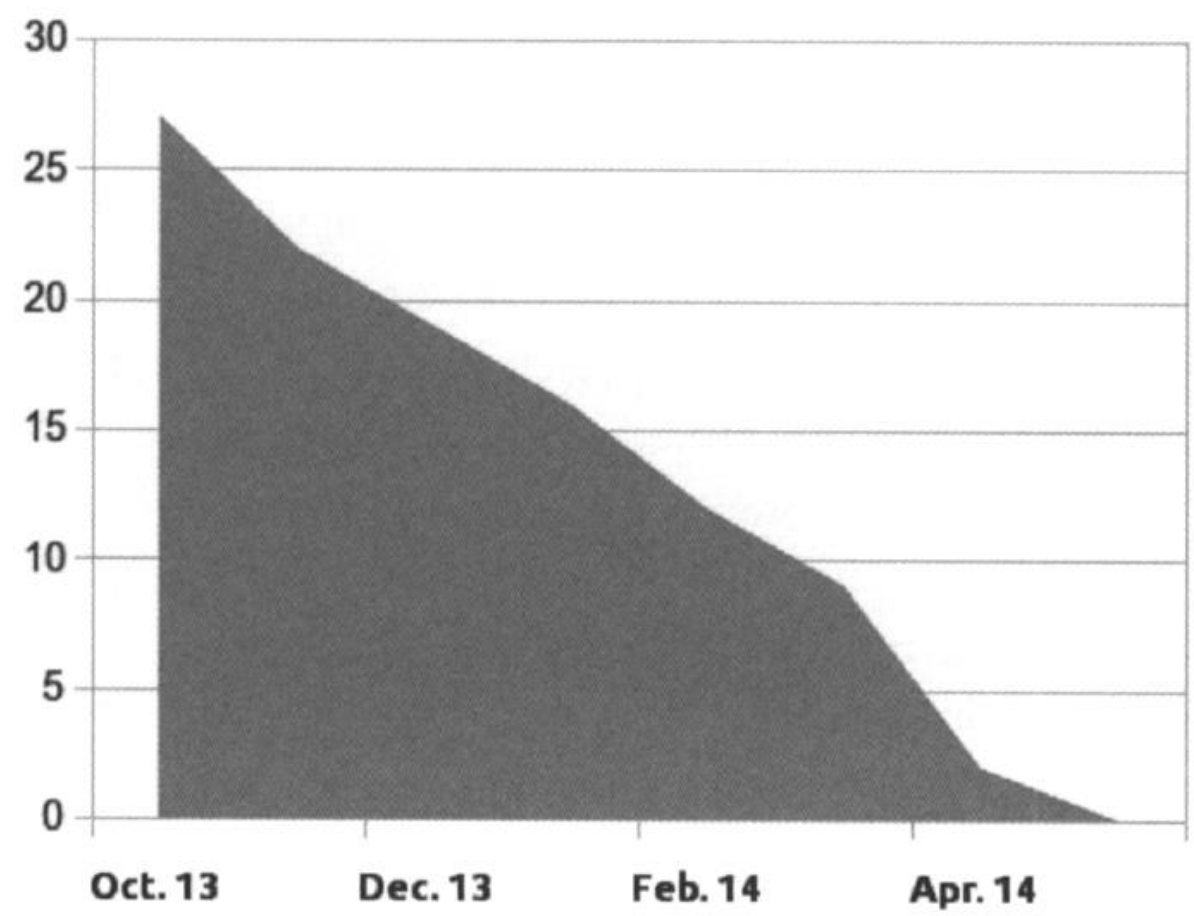

Figure 2 - Active participants

Twenty-eight people, ${ }^{11}$ lovers of contemporary art, took part in at least one of these events (they had been asked when enrolling to attend a minimum of five sessions). Participants were mostly young (half were aged between 25 and 34 years) and 80\% were women, which made this group the opposite of what is generally found on Wikipedia, where more than $80 \%$ of contributors are men.

In contrast to the initial aims of the project, the number of articles produced was relatively small, only about 15 . Considering the overall length of the project (40 hours) and the time invested by the teams, this number must be considered in the final evaluation as a negative point. 
Several things can explain this relative lack of success:

1. a mixed public, with particular expectations and different abilities, as one of the participants summarised: The group that came together was made up of some people who were very comfortable with the software, capable of adapting to it almost instantaneously, and others who had many difficulties.

2. the disappearance of contributors as the events progressed, which can perhaps be explained by the frequency of the weekly meetings, which implied considerable commitment, and also by the changing schedule.

3. the complexity of working on articles about recent works, because of questions connected with copyright on the illustrations.

However this can be put into perspective if one takes into account that on average each of these articles saw its size grow by 5,000 characters, ${ }^{12}$ a figure which should be compared with the average size of an article, which in 2014 was around 4,100 characters. ${ }^{13}$ And one should make note of a really good article originating in this project, on the subject of the Violon d'Ingres $^{14}$ by Man Ray, which is, today, a properly sourced article of several pages, whereas before the project it contained only one non-sourced paragraph. ${ }^{15}$

\section{The Bibliothèque Kandinsky workshops}

The second type of working group targeted a more specific public, and worked better overall. In fact, signing up for these workshops was oriented towards the Pompidou Centre's scholarship students, as well as contributors to the exhibition catalogues and staff of the Bibliothèque Kandinsky. The aim of the workshops was to improve articles about past exhibitions held by the Pompidou Centre's Musée national d'art moderne, some 30 of which had been identified for development on Wikipedia.

Participants in these workshops were more homogeneous and despite the overall length of each event being shorter, what was achieved was more worthwhile, because each person made a greater contribution: an average of 61,000 characters (equivalent to an estimated 30-plus pages of text). In the course of the four four-hour sessions, the contributors were able to create adequately-detailed articles on a number of exhibitions: Traces du sacré, Danser sa vie or Los Angeles 1955-1985.

Access to the documentary resources of the institution was a positive point that was stressed by several of the participants, one of them even stating that "it is essential to continue [the WikiCP project] but with a more coherent group, and fewer workshops..., and in particular with a great deal 
of direct access to the documentation".

\section{Other partnerships}

The Pompidou Centre wiki workshops are only one example of activity carried out by Wikimédia France in conjunction with cultural institutions. The next section of this article gives a rapid résumé of several others, in order to demonstrate a greater range of the opportunities available.

\section{Château de Versailles}

The Château de Versailles was, in 2011, one of the first major cultural institutions to sign a partnership with Wikimédia France, and this agreement led to the establishment for six months of a trainee, a 'wikipedian in residence', at the chateau. The aim of the traineeship was to enrich the online content that already existed about the Château by means of several different projects. In particular it saw the creation of a portal on Wikipedia which today brings together more than 400 online articles on the Château, of which five are 'articles of quality' and three 'good articles'. The curators and the wikipedians were both involved, working together either over a long period or in 'marathons' of 24 hours.

This six-month period was also an opportunity to propose privileged access to the Château by the wikimedians, to allow them to take photographs. Currently the section devoted to these images on Wikimedia Commons contains 2,305 16 files and these have been used several hundreds of times in 92 different wikis ${ }^{17}$, as illustration 3, which comes from Bulgaria's Wikipedia, shows.
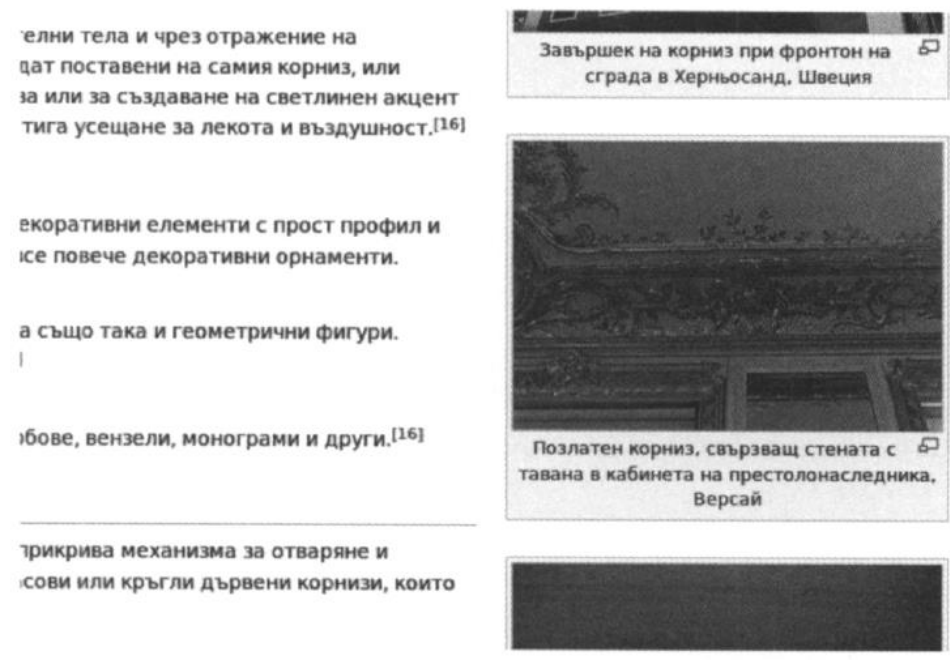

Figure 3 - Wikipedia in Bulgarian

\section{Musée des Arts Décoratifs editathon}


In March 2014, within the framework of a project supported by Europeana entitled 'fashion editathons', Wikimédia France and the Musée des Arts Décoratifs together organised a day dedicated to contributing to Wikipedia. The principle was similar to that of the Pompidou Centre wiki project but over a shorter period: three hours of initiation for the new wikipedians a week before the event, covering the theory of contributing, followed by a complete day of article creation. During the course of this day, 17 articles were created, representing more than 110,000 characters of content $^{18}$,and 15 articles that already existed were enlarged by more than 80,000 characters. ${ }^{19}$

\section{Contributing images}

This section deals not with one partnership in particular but rather a principle shared by several French cultural institutions who have seen that Wikipedia offers a unique opportunity to make visible the content that they have already produced, most often digitized documents.

Each year, Wikimédia France works with libraries, museums or archives to put this digitized content online. The principle behind these activities is to find common ground between the subject descriptions produced by the cultural bodies and the way the content is described on Wikimedia Commons, to add these images automatically using import tools ${ }^{20}$, and to promote the resulting content in order to encourage its use in projects.

Initiatives are also under way to make institutions as autonomous as possible, notably by adapting and installing a set of tools that facilitates batch uploads of images and statistical follow-up, and the encourages re-use of the enriched content the community has achieved. This project, the product of a partnership between a number of Wikimedia associations and Europeana, is known as the 'GLAMwiki Toolset project'. ${ }^{21}$

The growth in visibility of this type of project is well-known nowadays, and it is enough to quote a couple of examples. The first concerns the German federal archives which, after putting 100,000 images on Wikimedia Commons in 2008, saw research queries grow by $230 \%{ }^{22}$. The second was at the Museum d'Histoire Naturelle de Toulouse, which allowed wikimedians to produce images of objects in its collections. These images, of high quality, could be re-used in different high-quality publications (Nature, Encyclopedia Britannica, etc.) and contributed towards establishing the reputation of the museum. An unforeseen result was that it triggered the donation of a precious collection of shells from the Black Sea. ${ }^{23}$ The Ukrainian collector had become aware of the museum through the project. 


\section{Evaluation}

From the point of view of the participants, the experience seems to have been positive, since three quarters of those questioned declared themselves to be satisfied. ${ }^{24}$ However, and as we have seen in this article, the general assessment is less clear-cut. In terms of absolute value, Wikipedia is certainly richer in its coverage of the major themes of the Pompidou Centre, but the investment of time by the Centre's personnel and the wikipedians seems out of proportion to this enrichment. This is principally due to the fact that contributors did not stay the course. In fact, as image 2 shows, two months after the end of the workshops these contributors had no commitment whatsoever and none of the participants came back to participate in Wikipedia.

There were however two points that were pleasing. The first was the relative success of the online project with the Bibliothèque Kandinsky, which despite the fact that it was shorter resulted in the development of articles of good quality. The second is that, as a result of these workshops, some 40 people are now familiar with Wikimedia projects and are likely to come back and contribute, on modern art or on a completely different subject, especially those contributors who were most involved in the workshops. ${ }^{25}$

\section{Facts and figures}

The following tables show the creation and development of articles as a result of the Musée des Arts Décoratifs fashion editathon detailed in this article.

\begin{tabular}{|l|r|}
\hline \multicolumn{1}{|c|}{ Article created } & $\begin{array}{r}\text { Size measured in bits } \\
\text { 25/06/2014 }\end{array}$ \\
\hline Marchande de modes & 8859 \\
\hline Iris Van Herpen & 8540 \\
\hline Monument du costume & 7196 \\
\hline Charles James & 13282 \\
\hline Maison Lemarié & 4845 \\
\hline Walter Van Beirendonck & 3338 \\
\hline Costume élisabéthain & 14415 \\
\hline Mode sous le Second Empire & 12151 \\
\hline Bianchini-Férier & 4822 \\
\hline Roberto Capucci & 5177 \\
\hline Sources de l'histoire du costume & 7708 \\
\hline Kansai Yamamoto & 4371 \\
\hline Muguette Buhler & 705 \\
\hline Fleuriste artificiel & 8560 \\
\hline
\end{tabular}




\begin{tabular}{|c|c|}
\hline Article created & $\begin{array}{c}\text { Size measured in bits } \\
25 / 06 / 2014\end{array}$ \\
\hline Drecoll & 1836 \\
\hline Agnès-Drecoll & 2463 \\
\hline Total & 108,268 \\
\hline
\end{tabular}

Table 1: Articles created in the course of the fashion editathon

\begin{tabular}{|l|r|r|r|r|}
\hline \multicolumn{1}{|c|}{ Modified article } & Original size & Size (in bits) at & \multicolumn{2}{|c|}{ Enrichment } \\
\cline { 4 - 6 } & & $25 / 06 / 2014$ & In bits & Percentage increase \\
\hline Textiles intelligents & 18555 & 19101 & 546 & 3 \\
\hline Visual merchandising & 5142 & 10936 & 5794 & 113 \\
\hline Marcel Rochas & 1719 & 6946 & 5227 & 304 \\
\hline Chapeau & 20087 & 32194 & 12107 & 60 \\
\hline Jean-Henri Eberts & 2616 & 6540 & 3924 & 150 \\
\hline Kermes vermilio & 3627 & 4907 & 1280 & 35 \\
\hline Jean Patou & 7108 & 16425 & 9317 & 131 \\
\hline Tapisserie & 14483 & 18774 & 4291 & 30 \\
\hline Châle & 9308 & 11437 & 2129 & 23 \\
\hline Cristóbal Balenciaga & 19519 & 39477 & 19958 & 102 \\
\hline Histoire du costume & 49894 & 57482 & 7588 & 15 \\
\hline Magazine de mode & 2369 & 4685 & 2316 & 98 \\
\hline Cinémathèque & 1389 & 2916 & 1527 & 110 \\
\hline Robert-Lynen & & & & 208 \\
\hline Mode en 1900 & 2584 & 7963 & 5379 & 123 \\
\hline Métier à tisser & 2069 & 4607 & 2538 & 52 \\
\hline & 160,469 & 244,390 & 83,921 & \\
\hline Total & & & & \\
\hline
\end{tabular}

Table 2: Existing articles enriched during fashion editathon

\begin{tabular}{|l|l|r|r|}
\hline$\#$ & \multicolumn{1}{|c|}{ Nickname } & Contributions & Contribution size (in bits) \\
\hline 1 & Albine Daruce & 277 & 172000 \\
\hline 2 & Nijimi1 & 130 & 119000 \\
\hline 3 & Kakushka & 103 & 154000 \\
\hline 4 & Mipaba & 86 & 80000 \\
\hline 5 & SoniaDesk & 83 & 63000 \\
\hline 6 & EnricoCmp & 80 & 25000 \\
\hline 7 & Anne-Marie 2607 & 76 & 16000 \\
\hline 8 & AuriP & 52 & 39000 \\
\hline 9 & Marinakj & 44 & 5400 \\
\hline
\end{tabular}




\begin{tabular}{|c|c|c|c|}
\hline$\#$ & Nickname & Contributions & Contribution size (in bits) \\
\hline 10 & Rositaami & 39 & 17000 \\
\hline 11 & Carota & 34 & 6400 \\
\hline 12 & Margueritevandeau & 31 & 12000 \\
\hline 13 & Dorai07 & 31 & 7100 \\
\hline 14 & Remiforall & 30 & 7700 \\
\hline 15 & Pseudo88 & 29 & 4100 \\
\hline 16 & Lamarta & 26 & 24000 \\
\hline 17 & Frini87 & 22 & 6300 \\
\hline 18 & Leballeur & 20 & 5800 \\
\hline 19 & Morganelair & 19 & 2500 \\
\hline 20 & Boulinguez Pablo & 19 & 2700 \\
\hline 21 & Laelan & 15 & 817 \\
\hline 22 & Aireine & 14 & 9600 \\
\hline 23 & Il Grande Cocomero & 13 & 43000 \\
\hline 24 & Mariedebandcillet & 10 & 1200 \\
\hline 25 & Clara Lily & 10 & 3300 \\
\hline 26 & Gonzagauthier & 9 & 3600 \\
\hline 27 & Cilineweb & 9 & 4100 \\
\hline 28 & Comme.losange & 7 & 3500 \\
\hline 29 & Julenouri & 6 & 2400 \\
\hline 30 & Regarddamateur & 6 & 331 \\
\hline 31 & EB1978 & 6 & 1000 \\
\hline 32 & Mountainbirds & 5 & 501 \\
\hline 33 & Salvo2013 & 4 & 198 \\
\hline 34 & Nijimi & 3 & 53 \\
\hline 35 & Petitspoissalés & 2 & 132 \\
\hline 36 & Arthie123 & 2 & 28 \\
\hline
\end{tabular}

Table 3: Activity ${ }^{26}$ by the participants in the project at Centre Pompidou ${ }^{27}$

This article is a translation of "Amélioration des articles sur l'art moderne dans Wikipédia: Partenariat entre Wikimédia France et le Centre Pompidou”, a paper delivered at the IFLA Art Libraries Section satellite conference Art libraries meet the challenges of E-publishing: new formats, new players, new solutions, held in Paris at the Institut national d'histoire d'art, 12 - 14 August 2014. The article has been translated by Gillian Varley. 


\section{References}

1. Wikimedians are the contributors to the projects, amongst whom the majority are the wikipedians, contributors to Wikipédia.

2. Commons: Bibliothèque Nationale de France/fr - Wikimedia Commons. https://commons.wikimedia.org/wiki/Commons:Biblioth\%C3\%A8que_nationale_de_France/fr, accessed 25 June 2014.

3. Optical Character Recognition, a technology allowing identification of the characters on a page of digitised text (and translating the images into a form that can be manipulated by a computer).

4. “Ateliers au Centre Pompidou pour créer des articles Wikipédia sur l’art moderne” Wikimedia blog, 20 August 2011. http://blog.wikimedia.fr/ateliers-au-centre-pompidou-pour-creer-des-articleswikipedia-sur-1\%E2\%80\%99art-moderne-3262, accessed 2 March 2015.

5. “Centre Pompidou Virtuel”. http://www.centrepompidou.fr/, accessed 25 June 2014.

6. Céline Rabaud. "La participation contributive des publics et des personnels au musée: l'exemple du partenariat entre Wikimédia France et le Centre Pompidou.” Université Sorbonne nouvelle. 3 (2014): 71.

7. Gonzague Gauthier. “\#WikiCP: How this partnership between Centre Pompidou and Wikimedia France works.” Véculture, http://gonzaggauthier.wordpress.com/2013/10/05/wikicp-how-thispartnership-between-centre-pompidou-and-wikimedia-france-works/, accessed 25 June 2014.

8. "Wikipédia: Articles de qualité.” Wikipédia, 9 June 2014. https://fr.wikipedia.org/wiki/Wikip\%C3\%A9dia:Articles_de_qualit\%C3\%A9.

9. "Wikipédia: Principes fondateurs.” Wikipédia, 31 May 2014. https://fr.wikipedia.org/wiki/Wikip\%C3\%A9dia:Principes_fondateurs.

10. Some of the contributors are enabled to perform special actions (like suppressing pages, blocking users), by agreement with the decisions of the community.

11. "Projet: Centre Pompidou/Participants.” Wikipédia. https://fr.wikipedia.org/wiki/Projet:Centre_Pompidou/Participants, accessed 25 June 2014.

12. Céline Rabaud. "La participation contributive des publics et des personnels au musée: l'exemple du partenariat entre Wikimédia France et le Centre Pompidou.” Université Sorbonne nouvelle. 3 (2014): 76.

13. "Wikipedia statistics - - charts http://stats.wikimedia.org/EN/ChartsWikipediaFR.htm\#2, accessed 25 June 2014.

14. “Le Violon d'Ingres.” Wikipédia, 22 June 2014. https://fr.wikipedia.org/wiki/Le_Violon_d\%27Ingres.

15. “Le Violon d'Ingres, version du 6 novembre 2013,” Wikipédia, 22 June 2014. https://fr.wikipedia.org/wiki/Special:PermanentLink/98081257. 
16. “Category: All images from the partnership with the Château de Versailles.” Wikimedia Commons.

https://commons.wikimedia.org/wiki/Category:All_images_from_the_partnership_with_the_Ch\%C 3\%A2teau_de_Versailles, accessed 26 June 2014.

17. “Glamorous Tool - résultats sur la catégorie dédiée.” http://bit.ly/1nJWQZS, accessed 26 June 2014.

18. Cf. Table 1.

19. Cf. Table 2.

20. Import tools are computer programmes which allow automatic loading onto Wikimedia Commons of files and their associated metadata.

21. "Commons: GLAMwiki Toolset Project." Wikimedia commons. https://commons.wikimedia.org/wiki/Commons:GLAMwiki_Toolset_Project, accessed 26 June 2014.

22. HaeB and Resident Mario, "No further Bundesarchiv image donations; Dutch and German Awards; Anniversary Preparations.” The Wikipedia signpost, 22 November 2010. https://en.wikipedia.org/wiki/Wikipedia:Wikipedia_Signpost/2010-11-22/News_and_notes.

23. Dominique Delpiroux, “Les trésors du muséum sont visibles par le monde entier.” La dépêche, 28 January 2013. http://www.ladepeche.fr/article/2013/01/28/1546638-les-tresors-du-museum-sontvisibles-par-le-monde-entier.html.

24. Céline Rabaud. "La participation contributive des publics et des personnels au musée: l'exemple du partenariat entre Wikimédia France et le Centre Pompidou.” Université Sorbonne nouvelle. 3 (2014): 79.

25. Cf. Table 3.

26. "Statistiques utilisateurs - Catégorie: Utilisateur participant au projet Centre Pompidou." Wikiscan.

http://wikiscan.org/?menu=userstats\&userlist=Cat\%C3\%A9gorie\%3AUtilisateur+participant+au+p rojet+Centre+Pompidou, accessed 26 June 2014.

27. “Catégorie: Utilisateur participant au projet Centre Pompidou." Wikipédia. https://fr.wikipedia.org/wiki/Cat\%C3\%A9gorie3AUtilisateur+participant+au+projet+Centre+Pompi dou, accessed 26 June 2014. 